\title{
Mineralogical, geochemical and stable isotope studies of kaolin deposits in north-west Gonabad district (eastern Iran)
}

\author{
Sedigheh ZIRJANIZADEH ${ }^{1, *}$, Fernando ROCHA ${ }^{2}$ and Somayeh SAMIEE ${ }^{1}$ \\ 1 University of Gonabad, Faculty of Science, Geology Department, Iran \\ 2 University of Aveiro, Geobiotec Research Unit, Department of Geosciences, 3810-193 Aveiro, Portugal
}

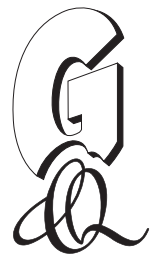

Zirjanizadeh, S., Rocha, F., Samiee, S., 2018. Mineralogical, geochemical and stable isotope studies of kaolin deposit in north-west Gonabad district (eastern Iran). Geological Quarterly, 62 (2): 385-399, doi: 10.7306/gq.1414

\begin{abstract}
Kaolin deposits, situated $\sim 10 \mathrm{~km}$ north-west of Gonabad (eastern Iran), formed by the intrusion of hydrothermal fluids from a granite dyke in the western part of the study area, and the alteration of rhyolite, dacite and rhyodacite related to Eocene volcanism. There are four major kaolin quarries. The rocks in the investigated area are mainly slate, dacite, rhyolite, andesite-trachyandesite, and lithic and felsic tuffs. The mineralogical compositions of the kaolin deposits are dominated by quartz, kaolinite, dickite and illite with minor chlorite, montmorillonite, albite, hematite, pyrite and gypsum. Sanidine and plagioclase crystals in rhyolite-rhyodacite are sericitized and kaolinized. Whole rock chemistry of the kaolin deposits shows high contents of $\mathrm{SiO}_{2}$ and $\mathrm{Al}_{2} \mathrm{O}_{3}$. Enrichments of $\mathrm{Sr}$ in some samples demonstrate retention of $\mathrm{Sr}$ and depletion of $\mathrm{Rb}, \mathrm{Ba}, \mathrm{Ca}$ and $\mathrm{K}$ during hydrothermal alteration of sanidine and plagioclase within the volcanic units. The chondrite-normalized rare earth element patterns of the clay deposits show LREE enrichments (La/Lu) $)_{\mathrm{cn}}=6.75$ to 57.74 , pointing to kaolinization in low-pH waters. The isotope composition of the kaolin $\left(\delta^{18} \mathrm{O} \sim+5 \%\right.$ ) is consistent with formation at isotopic equilibrium with water of hydrothermal/magmatic origin. The mineralogical composition, REE contents and elemental ratios in these deposits suggest provenance of the kaolin deposits mainly from felsic rocks and hydrothermal fluids. The $\mathrm{O}$ isotopic character also supports these results.
\end{abstract}

Key words: kaolinite, Iran, REE, O isotope composition.

\section{INTRODUCTION}

Hydrothermal kaolinite deposits generally develop under the control of an active tectonic environment and with the presence of permeable units, so that hydrothermal fluids can circulate through the rocks (Murray and Keller, 1993). In the study area, hydrothermal kaolinite deposits typically occur within volcanic rocks. The area north-west of Gonabad is rich in clay mineralization (Miri Bidokhti, 2004; Gharibnavaz et al., 2007; Miranvari et al., 2007). These deposits are of economic importance. The region is located in the north of the geotectonic Lut Block, between $58^{\circ} 33^{\prime \prime}-58^{\circ} 38^{\prime \prime} \mathrm{E}$ and $25^{\circ} 34^{\prime \prime}-25^{\circ} 38^{\prime \prime} \mathrm{N}$ (Figs. 1-4). Three large kaolin deposits - Baghsiah, Rokhsefid (Fig. $5 A$ ), Yasmina, and a smaller one (Kalatehno) are located within an area of $\sim 7.5 \mathrm{~km}^{2}$. Baghsiah and Rokhsefid deposits are the most important sources of high-quality raw material (clay) for the ceramic industries in eastern Iran. These deposits comprise a silicified zone (silicified cap) and a kaolin zone of other minerals, being hosted by volcanic rocks such as rhyolite and rhyodacite (Fig. 5B-F). Based on ASTER mineral mapping of this area it was possible to identify mineral alteration zones.

\footnotetext{
* Corresponding author, e-mail: szirjanizadeh@yahoo.com Received: July 5, 2017; accepted: December 16, 2017; first published online: May 22, 2018
}

Spectral Angle Mappe (SAM) method (Kruse et al., 1993) is one of the best and easiest techniques for delineating the alteration zones. In other words, the most important capability of satellites in mining exploration is to recognize altered (especially clay) minerals. Image processing shows a wide range of clay minerals (Fig. 2; Zirjanizadeh et al., 2011). To date, the geological, mineralogical and geochemical features (in the Baghsiah, Rokhsefid and Yasmina deposits) have been studied with an emphasis on technological properties (Miri Bidokhti, 2004; Gharibnavaz et al., 2007; Miranvari, 2008). No detailed mineralogical and geochemical studies have been done for the alteration zones of kaolin deposits, and the origin of geothermal solutions responsible for the hydrothermal alterations has not been investigated to date. The goal of the present study was to improve and investigate the geological, mineralogical and geochemical aspects as well as the genesis of hydrothermal kaolinite deposits within Eocene volcanic rocks of Iran.

\section{REGIONAL GEOLOGY}

The study area is located in the northern Lut Block Zone (Fig. 1). According to Stocklin and Nabavi (1973), the Lut Block extends $>900 \mathrm{~km}$ in a north-south direction, from the Doruneh Fault in the north to the Jaz-Mourian Basin in the south, but it is only $200 \mathrm{~km}$ wide. The Lut Block is composed of pre-Jurassic metamorphic rocks and Jurassic sediments, intruded by differ- 


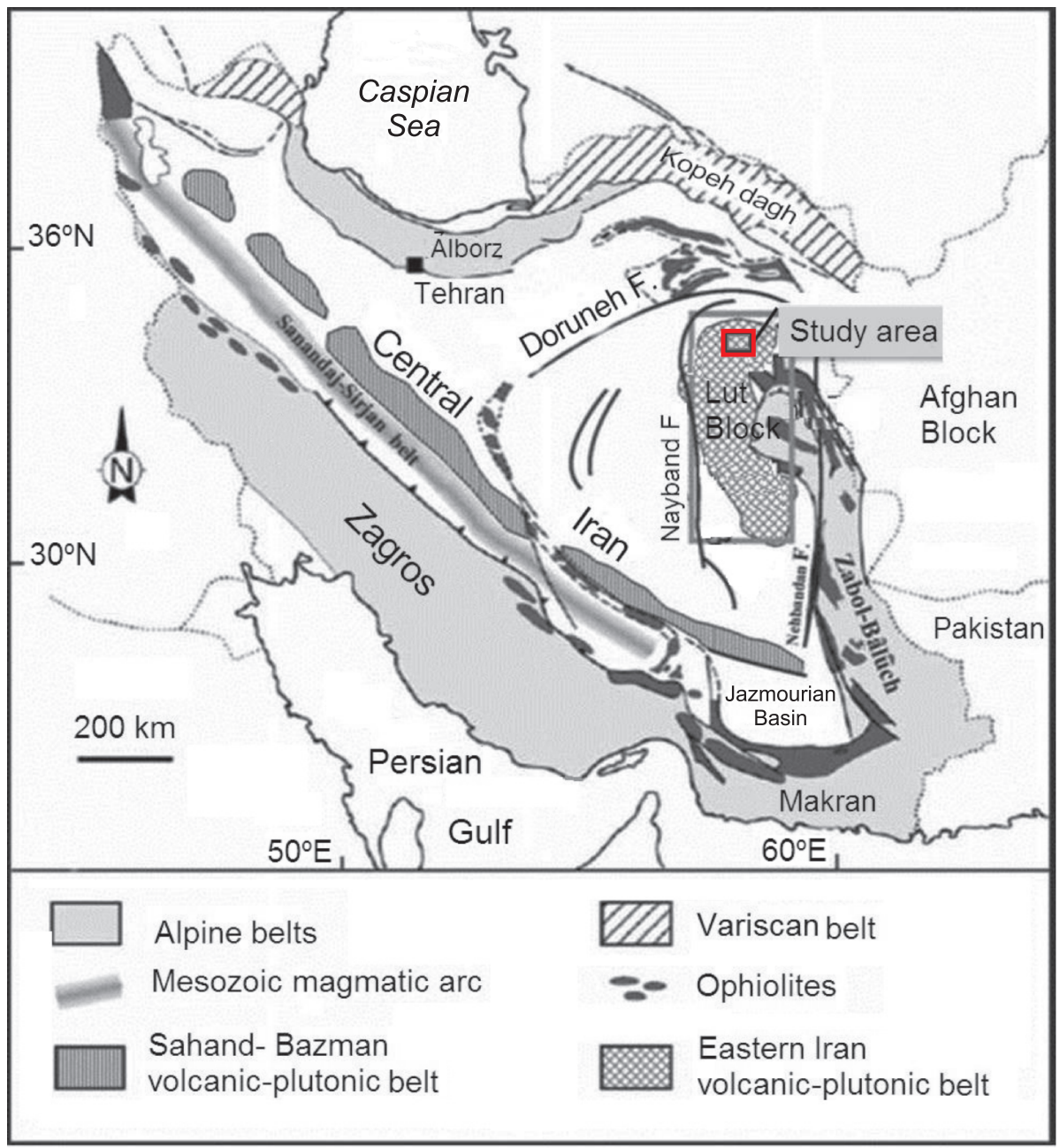

Fig. 1. Tectonic sketch-map of Iran

The red rectangle is the position of the study area, and the larger box indicates the location of the Lut Block (compiled from: Berberian, 1981; Alavi, 1991)

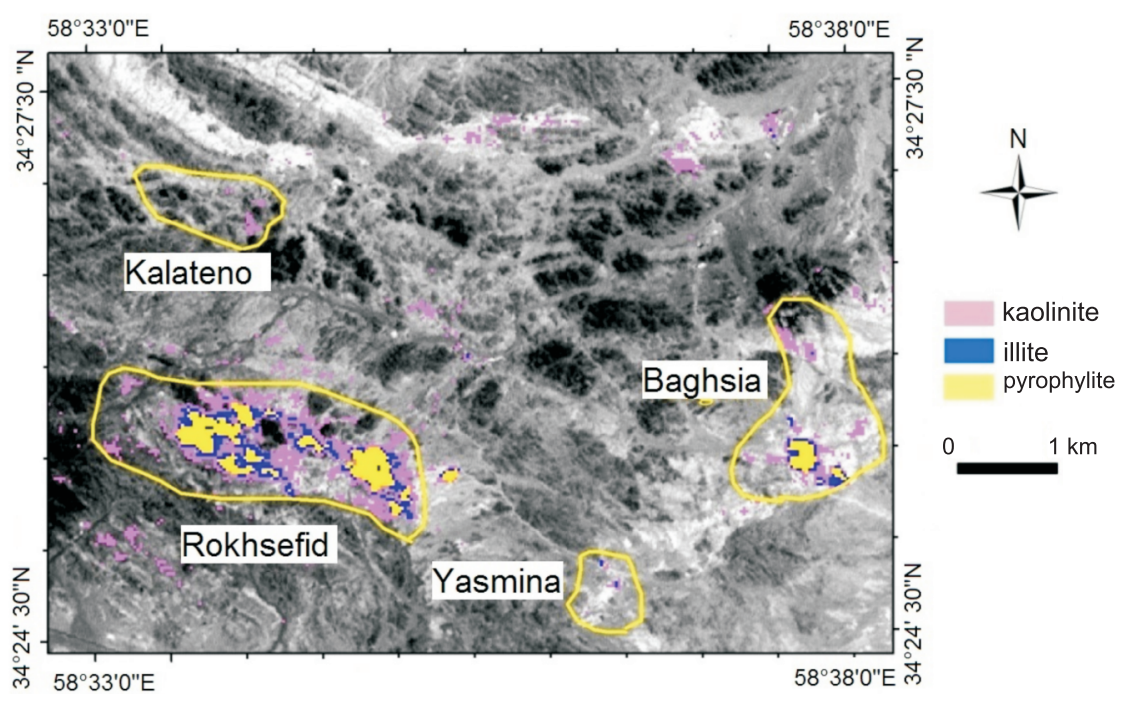

Fig. 2. Aster mineral mapping shows a real distribution of minerals interpreted to be clay minerals in the area of investigations (Zirjanizadeh et al., 2013) 


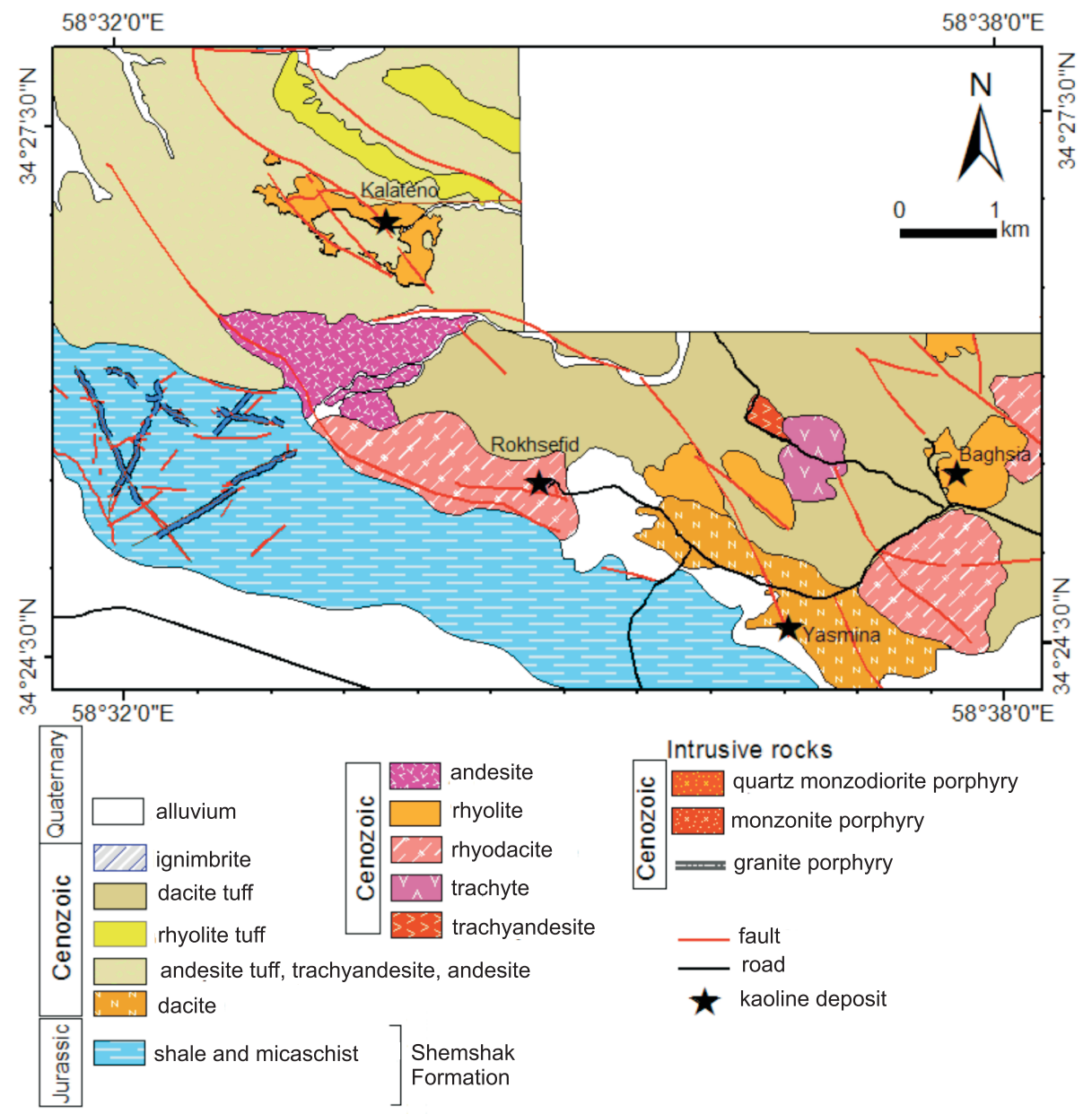

Fig. 3. Geological map of clay deposits area

ent generations of Jurassic and Paleogene/Neogene plutonic rocks, mainly granitoids, and covered by both effusive and explosive Paleogene/Neogene volcanic rocks ranging from basalt to rhyolite in composition. Volcanic and subvolcanic rocks of Paleogene/Neogene age cover over half of the Lut Block. They are up to $2000 \mathrm{~m}$ thick and formed due to subduction prior to the collision of the Arabian and Asian plates (Camp and Griffis, 1982; Tirrul et al., 1983; Berberian et al., 1999). In north-west Gonabad, epithermal systems are hosted in and formed contemporaneously with Paleogene/Neogene calc-alkaline volcanic rocks that were erupted in a syncollisional setting. The volcanic products outcrop along an $18 \mathrm{~km}$ long north-west-south-east trending structure in northern Gonabad.

\section{LOCAL GEOLOGY AND ALTERATION IN CLAY DEPOSITS}

Paleogene/Neogene volcanic rocks host the kaolin deposits (Zirjanizadeh et al., 2013; Fig. 3). The rocks of this area comprise slate, dacite, rhyolite, trachyandesite, andesite, acidic tuff rocks and some subvolcanic intrusions (porphyritic monzonite and monzodiorite; Fig. 3; Zirjanizadeh et al., 2013). The oldest unit (Shemshak Formation) is composed of slate and quartzite and is exposed west of the area. Jurassic shale and sandstone have been altered to slate and quartzite by regional metamorphism. Crystal tuff outcrops occur over most of the area (Fig. $6 \mathrm{~A})$. The volcanic units are greyish-green, white and pink. Vol- canic units of the Rokhsefid area consist of dacite, rhyodacite, andesite and tuffs and have gradational contacts with white to reddish white, moderately soft kaolinized and silicified zones. The kaolinite deposit is covered by a hard silica cap zone (Fig. 5F and Table 1). The silica cap is dark grey and has been brecciated. It shows several stages of hydrothermal alterations with high silica content (Gharibnavaz et al., 2007). Andesite-rhyolite tuffs are the main host rock of the Kalatehno deposit. Kaolin minerals of this deposit are grey to yellow, moderately hard, and contain pyrite and Fe oxides. XRD data confirms the presence and type of clay minerals in the deposits (Fig. 7 and Table 1). Volcanic rocks in the Baghsiah and Yasmina area consist of trachyandesite, rhyolite, dacite-rhyodacite, and green and pinkish tuffs. Rhyolitic, rhyodacitic and dacitic rocks are kaolinized. Petrographically, the volcanic units have porphyric, trachytic and sieve textures. In andesite-trachyandesite, phenocrysts include $25 \%$ plagioclase, $5 \%$ hornblende and $2 \%$ alkali feldspar altered to sericite (Fig. 6B). Groundmass comprises 30 to $35 \%$ plagioclase microlites and 10 to $15 \%$ opaque mineralisation. Carbonates are rarely found within the plagioclase and in the matrix - up to $10 \%$. Chlorite $(<3 \%)$ is scattered. Trachyte is distinguished by trachytic texture. Sanidine forms $90 \%$ of this rock. Hornblende is filled by 3 to $5 \%$ of carbonates; carbonates can be also found as veinlets and in the groundmass - up to $2 \%$. Other volcanic rocks in the area are dacite and rhyodacite. Phenocrysts include 3 to $5 \%$ quartz, 7 to $10 \%$ plagioclase, $5 \%$ hornblende and $1 \%$ biotite. The matrix contains $15 \%$ of sanidine altered to clay minerals (Figs. 4 and 6C). Monzonite porphyry and quartz monzodiorite porphyry are exposed at very 


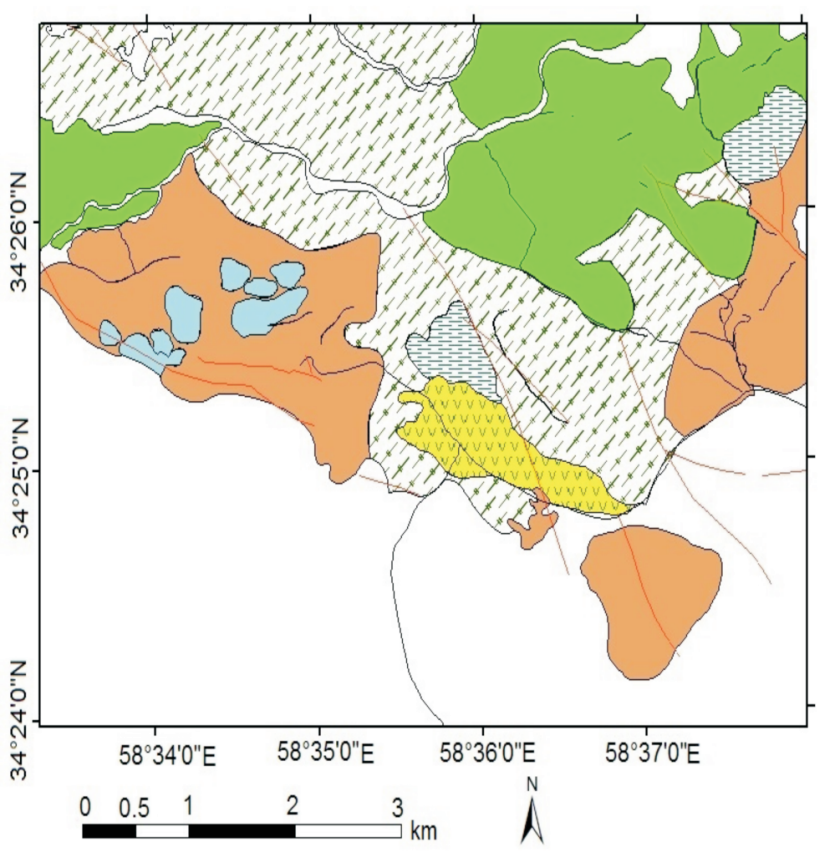

advance argillic + silicification strong silicification argillic + silicification + carbonate silicification + argillic + weak propylitic

Fig. 4. Alteration map of study area

few sites in the area. Potassium feldspar and plagioclase occur as phenocrysts. Alterations within these units are represented by silicification and sericitization (Fig. 6D, E). Accessory minerals are zircon and apatite. Figure 4 displays different alterations in this area. The primary texture of the volcanic rocks exposed in the quarry has not been observed, but may be preserved in areas of less intense alteration. An argillic alteration zone reaches $60 \mathrm{~m}$ in thickness. The common minerals, as determined by X-ray diffraction studies (Miri Bidokhti, 2004; Gharibnavaz et al., 2007; Miranvari et al., 2007), include kaolinite, quartz, K-feldspar, montmorillonite and illite. Main alteration types are argillic, advanced argillic, propylitic and silicification with different intensities and forming subzones. Indicator minerals of the advanced argillic zone include kaolinite, dickite, diaspore, sericite, pyrophyllite and, in some places, quartz, alunite, pyrite and tourmaline. Formation of minerals at this alteration zone strongly depends on hydrolysis, solution temperature and mineral compositions of the host rocks. Hydrothermal fluid(s) flushed through fault and fracture zones, and clay minerals typically were formed through the fractures. The kaolin deposits are oriented $\mathrm{E}-\mathrm{W}$. The main faults in this area are strike-slip faults, forming specific types of the structure (Ghaemi, 2005).

\section{MATERIALS AND METHODS}

About forty thin-sections from the studied volcanic rocks were examined under the optical microscope. In order to iden- tify the distribution of kaolinite and coexisting clays in the volcanic rocks, samples were collected from four different kaolin deposits. Clay mineral associations have been studied using X-ray diffraction (XRD). X-ray diagrams were obtained using a Philips Analytical X-Ray B.V. diffractometer. XRD analyses were performed using CuK $\alpha$ radiation and a scanning speed of $1^{\circ} 2 \theta / \mathrm{min}$. The mineral composition was determined both on unoriented powder mounts for bulk sample analyses and on oriented aggregates for the clay fraction ones. The clay fractions were separated by sedimentation according to Stokes law, using $1 \%$ sodium hexametaphosphate solution to avoid flocculation. For the preparation of preferentially oriented clay mounts, the suspension was placed on a thin glass plate and air-dried. Scans were run between $2^{\circ}$ and $60^{\circ} 2 \theta$ (unoriented powder mounts) or between $2^{\circ}$ and $20^{\circ} 2 \theta$ (oriented clay mounts) in the air-dry state after previous glycerol saturation and heat treatment $\left(300\right.$ and $500^{\circ} \mathrm{C}$ ). Qualitative and semi-quantitative mineralogical analyses followed the criteria recommended by Schultz (1964), Thorez (1976) and Mellinger (1979). For the semi-quantification of the identified principal minerals, peak areas of the specific reflections were calculated and weighted by empirically estimated factors, according to Galhano et al. (1999), Oliveira et al. (2002) and Martins et al. (2007). SEM and EDX analyses were made using a Leo 1450VP scanning electron microscope at the central laboratory of Ferdowsi University of Mashhad. Samples were prepared by dispersing dry powder on a double-sided conductive adhesive tape. Then, the samples were coated with Au-Pd, 180 s, with a Sputter coater SC7620 for SEM-EDX. Thirty-five bulk samples of fresh, moderately and highly altered volcanic units (clay deposits) were manually crushed and then analysed by wavelength-dispersive X-ray Fluorescence (XRF) spectrometry using fused discs and the Phillips PW 1480 XRF at the East Amethyst Laboratory in Mashhad, Iran, and for trace elements and rare-earth elements (REE) at ACME Analytical Laboratories Ltd., Vancouver (Canada). Fluid-inclusion studies were performed on doubly polished samples taken from the silicified cap. Microthermometric determinations were carried out at the Department of Geology, Ferdowsi University (Iran), using a Nikon Labophot-pol microscope mounted with a Linkam THMS-600 and TMS-92 freezing-heating stage. Four representative kaolinite-bearing samples from highly altered volcanic units (kaolin deposits) were purified and analysed for the oxygen isotope. Oxygene isotopes of kaolinite were measured in purified kaolinite. Kaolinite was purified via separation of the kaolinite $(<2 \mu \mathrm{m})$ by sedimentation, followed by centrifugation of the suspension, and after the overnight dispersion in distilled water. The kaolinite particles were dispersed by ultrasonic vibration for $\sim 15$ minutes. Oxygen isotope composition of purified samples was analysed in the Isotope Geochemistry Laboratory, University of Glasgow, Scotland. All whole rock powders were analysed using a laser fluorination procedure, involving total sample reaction with excess $\mathrm{ClF}_{3}$ using a $\mathrm{CO}_{2}$ laser as a heat source (in excess of $1500^{\circ} \mathrm{C}$; following Sharp, 1990). $\mathrm{O}_{2}$ released from the total fluorination of the samples was then converted to $\mathrm{CO}_{2}$ by reaction with hot graphite and then analysed on a VG Optima mass spectrometer. Oxygen isotope $\left(\delta^{18} \mathrm{O}\right)$ values are reported in the standard per mill (\%o) notation relative to the Vienna Standard Mean Ocean Water (V-SMOW). Reproducibility is better than $\pm 0.3 \%$ o (1s) based on repeated analyses of international and in-house standards run during these analyses - UWG2, SES and GP147 - giving values of $5.9 \%$ (versus the accepted value of 5.8\%o), 10.3\%o (accepted, 10.2\%o) and 7.1\%o (accepted, 7.2\%o) respectively, during analyses of these samples. Consequently, the obtained values of analyses show that the natural data are accurate and precise. 

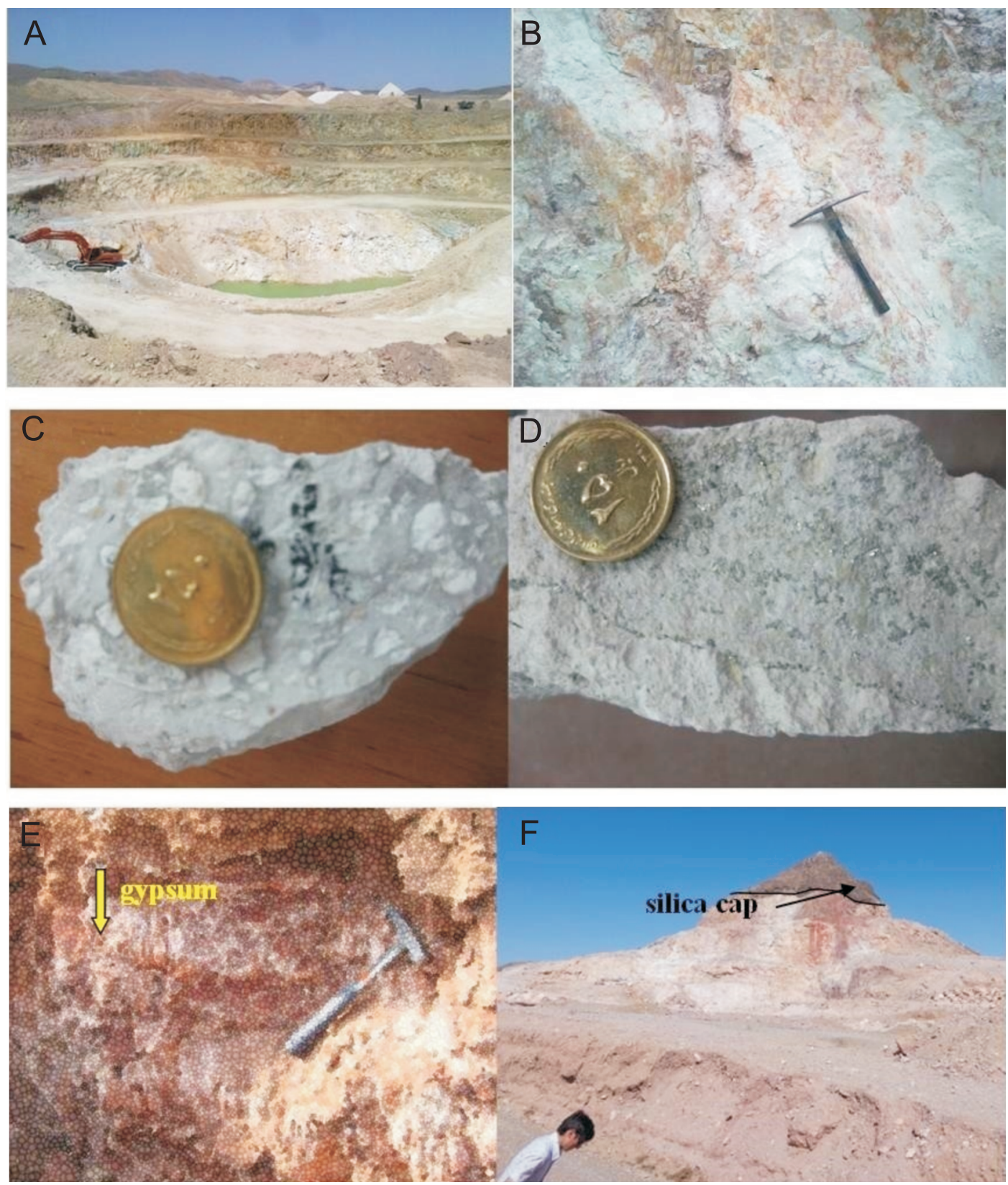

Fig. 5. Field photographs: A - a general view of the Rokhsefid kaolin deposit; B - close-up view of supergene and hypogene clays from the Kalatehno deposit; the effect of meteoric water on the top of hydrothermal clays; C - close-up view of partially altered rhyodacite (coin size: $22 \mathrm{~mm}$ ); D - sulphide minerals (pyrite) developed within the kaolinized unit (coin size: $22 \mathrm{~mm}$ ); E - gypsum/anhydrite and iron-oxide phases, along fractures in superficial parts of the Yasmina area; F-Rokhsefid kaolinite deposit and overlying silicified rocks (rhyolite and rhyodacite)

\section{RESULTS}

MINERALOGICAL FEATURES (XRD, SEM/EDX ANALYSES)

The kaolin minerals occur as chalky-white, greasy and massive bodies, or as fine-grained fragments or bodies within highly altered dacitic and rhyodacitic volcanic rocks and tuffs. The XRD patterns of bulk samples indicate that the major minerals are quartz, kaolinite, dickite, illite, pyrophyllite, beidellite and nacrite. Minor phases include alunite, chlorite, montmorillonite, muscovite, albite, hematite, pyrite and gypsum (Fig. 7 and Table 1).
According to Figure 8, solutions forming minerals in Kalatehno have the $\mathrm{pH}$ ranging between the stability of feldspars and kaolinite-pyrophyllite. However, the $\mathrm{pH}$ of solutions in Baghsiah, Rokhsefid and Yasmina are more acidic, and kaolin group minerals formed. The SEM studies revealed a range of clay mineral morphologies and fine-grained kaolinite crystals (Fig. 9A). Some kaolinite particles are $<1$ to $2 \mathrm{~mm}$ in size. The EDX spectrum shows the presence of $\mathrm{Al}, \mathrm{Si}$, and $\mathrm{O}$ along with minor concentrations of $\mathrm{K}$ and $\mathrm{Fe}$ (Fig. 9B). Some platelets with hexagonal edges and book shapes were observed as well, and the EDX spectrum shows that these small platelets are composed of $\mathrm{Al}, \mathrm{Si}$, and $\mathrm{O}$ (Fig. 9C). The parent rocks are tuffs and rhyolite-rhyodacite containing feldspar. Based on SEM/EDX studies, the alteration of 
Mineralogical composition of studied clay deposits

(based on XRD analyses; Miri, 2004; Gharibnavaz et al., 2007; Miranvari et al., 2007, and this study)

\begin{tabular}{|c|c|c|c|c|c|}
\hline Mine & Sample & $X$ & Y & Major phase & Minor phase \\
\hline \multirow{2}{*}{ Baghsiah } & BK51-2 & 649609 & 3810433 & quartz & kaolinite-montmorillonite \\
\hline & BK53-3 & 649693 & 3810331 & quartz & montmorillonite-kaolinite \\
\hline \multirow{3}{*}{ Yasmina } & Yass1 & 648925 & 3808237 & quartz & kaolinite-pyrophylite-montmorillonite \\
\hline & $\mathrm{Kg} 47^{*}$ & 648700 & 3808237 & quartz-kaolinite & chlorite \\
\hline & $\mathrm{Kg} 2^{*}$ & 647996 & 3808659 & quartz-kaolinite & montmorillonite-chlorite \\
\hline \multirow{8}{*}{ Rokhsefid } & $\mathrm{A} 22$ & 3810185 & 645193 & quartz & clinochlore, dickite \\
\hline & Ghar & 645018 & 3810196 & quartz & clinochlore, dickite \\
\hline & EGA3* & 645269 & 3810015 & quartz & montmorillonite \\
\hline & $\mathrm{AW}^{*}$ & 645170 & 3810250 & quartz & kaolinite-montmorillonite \\
\hline & $\mathrm{AL} 1^{*}$ & 645278 & 3810112 & kaolinite-quartz & montmorillonite-hydrohematite \\
\hline & $\mathrm{AE} 5^{*}$ & 645224 & 3810173 & kaolinite-quartz & montmorillonite-hematite-calcite \\
\hline & $\mathrm{R} 22^{*}$ & 645118 & 3810366 & quartz & hematite \\
\hline & R33* & 645130 & 3810324 & quartz-alunite & kaolinite-hematite \\
\hline \multirow{5}{*}{ Kalatehno } & Geo1 & 643882 & 3813139 & quartz-Illite-muscovite & \\
\hline & Geo2 & 643821 & 3813205 & quartz-albite-montmorillonite-palygorskite & \\
\hline & Geo3 & 643452 & 3813107 & quartz-Illite-muscovite & \\
\hline & Geo4 & 643456 & 3813125 & quartz-IIlite-orthoclase-albite & \\
\hline & Geo5 & 643456 & 3813125 & $\begin{array}{l}\text { quartz-muscovite-orthoclase- } \\
\text { albite-gypsum }\end{array}$ & \\
\hline
\end{tabular}

*Data for Rokhsefid mine from Gharibnavaz et al. (2007) and data for Yasmina mine from Miranvari (2008)

feldspar takes place in these epithermal environments and kaolinite/dickite may have been formed from dissolution of feldspar.

Baghsiah and Rokhsefid areas. These kaolin mineral bodies of various thicknesses (ranging from $50 \mathrm{~m}$ to $>80 \mathrm{~m}$ ) are located next to each other. The sampled hand specimens are mostly white, but they are seen also in yellow, orange, brown and dark brown colour due to increase of Fe and Ti oxides (Appendix $\left.1^{*}\right)$. With the increasing amount of silica, the mineral samples are harder, rougher, and have sharp fractured surfaces, whereas the purer samples appear soapy to the touch and are soft and powdery. Hematite and pyrite are observed in the Baghsiah deposit. The mineralogy of these deposits is listed in Table 1.

Yasmina area. Yasmina deposit comprises kaolinite, quartz, pyrophyllite and sericite as main minerals, and chlorite, illite, montmorillonite, albite and sanidine as accessory minerals (Miranvari, 2008; Fig. 7 and Table 1). Comparing the mineralogical composition of Yasmina with Rokhsefid and Baghsiah, there are no hematite and pyrite in Yasmina. There are large masses of gypsum in some areas up to $20 \mathrm{~cm}$ or more, in the superficial portions.

Kalatehno area. The Kalatehno deposits contain quartz, illite, muscovite, montmorillonite, albite, orthoclase, gypsum, pyrite and hematite (Fig. 7 and Table 1). The meteoric water and hydrothermal fluids resulted in the formation of two types of supergene and hydrothermal clays. The supergene clays are deposited at the top of the hydrothermal clays; consequently, abundances of these minerals depend on sample location within the weathering profile, and presumably also on primary lithological variations of the parent rocks. For instance, feldspars decrease upwards and, by contrast, muscovite and/or illite increase downwards in the vertical profile. Coarse pyrite is observed in the Kalatehno area in vein and disseminated forms, in comparison with Yasmina, Rokhsefid and Baghsiah.

\section{BULK-ROCK CHEMICAL FEATURES}

Geochemically, the fresh volcanic rocks (parent rock, Appendix 1) are rich in potassium, calc-alkaline in nature, metaluminous, enriched in LREE/HREE with $\mathrm{La}_{N} / \mathrm{Yb}_{N}$ ranging from 3.53 to 15.47, and show negative Eu anomalies (Appendix 2). Generally, enrichments in $\mathrm{Al}_{2} \mathrm{O}_{3}$ and $\mathrm{SiO}_{2}$ and depletions of $\mathrm{K}_{2} \mathrm{O}, \mathrm{TiO}_{2}$ and $\mathrm{CaO}$ were discerned from fresh to moderately altered samples (Appendix 1).

\section{GEOCHEMISTRY OF MAJOR ELEMENTS IN CLAY DEPOSITS}

Yasmina area. The $\mathrm{SiO}_{2}$ concentration in the Yasmina deposit (Appendix 1) is high (avg. 71.6\%), but the amount of $\mathrm{Al}_{2} \mathrm{O}_{3}$ 

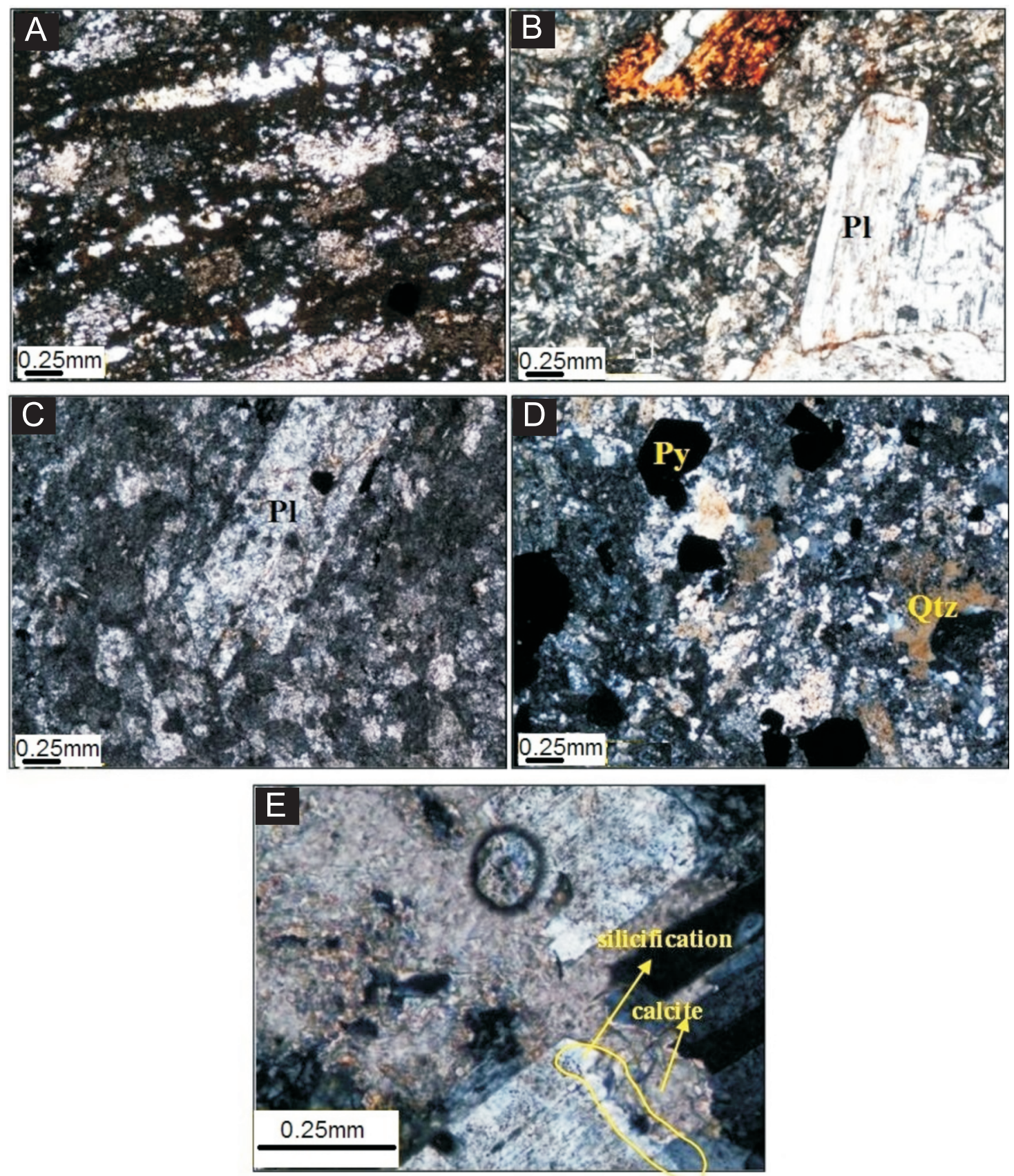

Fig. 6. Photomicrographs

A - tuff with groundmass altered to argillic (PPL); B - altered feldspar within andesite (XPL); C - plagioclase altered to clay minerals in rhyodacite (XPL); $\mathbf{D}$ - silicification, sericite and opaque minerals in quartz monzonite porphyry (XPL); E - plagioclase crystals are broken and filled by calcite; quartz has grown in the margins of plagioclase; PPL plane-polarized light; XPL - cross-polarized light; PI - plagioclase; Py - pyrite; Qtz - quartz

is low (avg. 18.8\%). The $\mathrm{CaO}$ value is low $(0.7 \%)$ and the percentage of $\mathrm{K}_{2} \mathrm{O}$ is $2.2 \%$. The total $\mathrm{Fe}$ (avg. $0.9 \%$ ) and $\mathrm{TiO}_{2}$ contents (avg. $0.2 \%$ ) are low.

Baghsiah and Rokhsefid deposits. Clays from these deposits show average amounts of $20.5 \% \mathrm{Al}_{2} \mathrm{O}_{3}, 71.6 \% \mathrm{SiO}_{2}, 1.4 \%$ $\mathrm{Fe}_{2} \mathrm{O}_{3}$ and $0.7 \% \mathrm{TiO}_{2}$ (Appendix 1). Because of high silica, the clays have high roughness. $\mathrm{TiO}_{2}$ is as much as a maximum of $1.5 \%$ in Rokhsefid, whereas it is between 0 to $1.5 \%$ in the other deposits. $\mathrm{K}_{2} \mathrm{O}$ content is negligible. The presence of alunite below water table shows that meteoric waters have leached $\mathrm{K}_{2} \mathrm{O}$ and alunite formed. Occurrence of alunite indicates an acid environment with a pH between 2 and 4 (Hemley et al., 1969; Stoffregen, 1987; Fig. 7 and Table 1; sample no: R33).

Kalatehno area. Chemical analyses of whole rocks revealed high percentage of $\mathrm{SiO}_{2}$ (avg. 61.0\%) and low amount of alumina (avg. 17.7\%); $\mathrm{K}_{2} \mathrm{O}$ (avg. $4.1 \%$ ) reflects the presence of illite and K-feldspar (Table 1; Appendix 1). The average $\mathrm{SiO}_{2}$ content $(61.0 \%)$ in Kalatehno is lower than that in Yasmina $(71.6 \%)$ and Rokhsefid $(64.5 \%)$ and higher than the average in Baghsiah (55.2\%). 

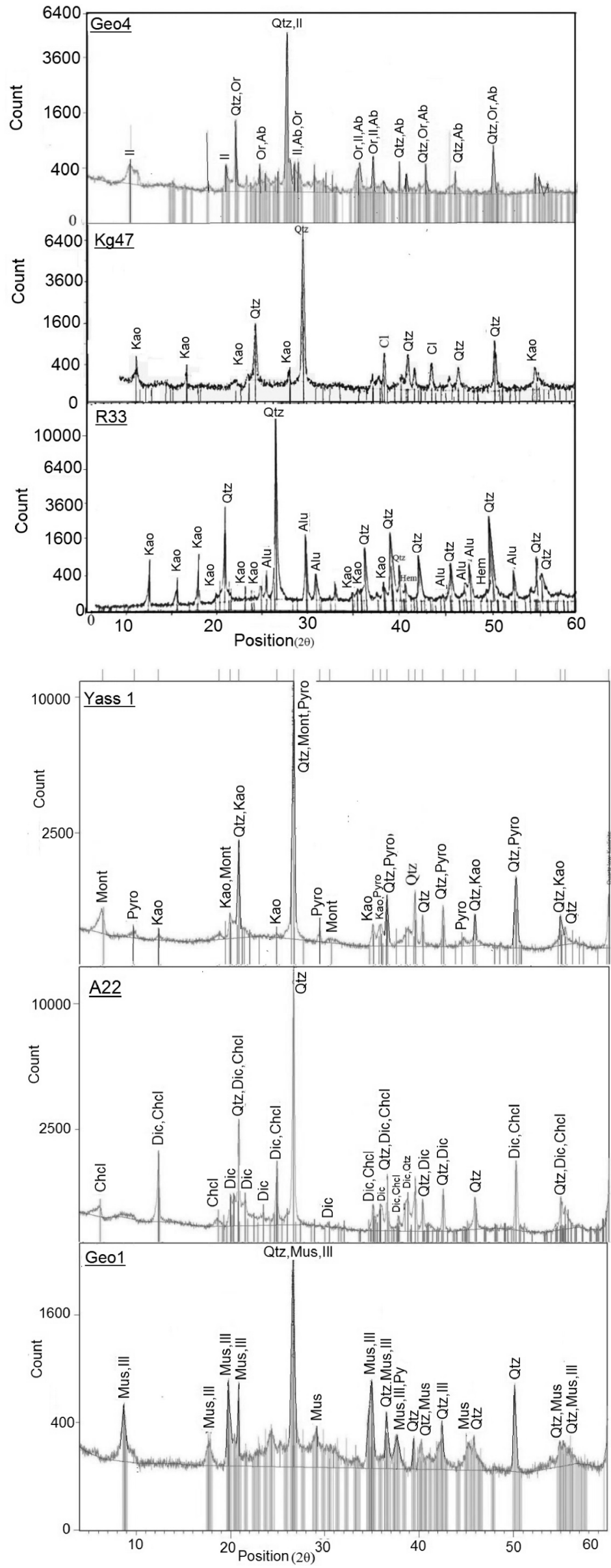

Fig. 7. X-ray diffraction patterns for samples from kaolin deposits

Pyro - pyrophyllite, Kao - kaolinite, Mus - muscovite, III - illite, Clch - clinochlore, Qtz - quartz, Mont - montmorillonite, $\mathrm{Plg}$ - plagioclase, $\mathrm{Ab}$ - albite, abbreviation of minerals from Whitney and Evans (2010) 


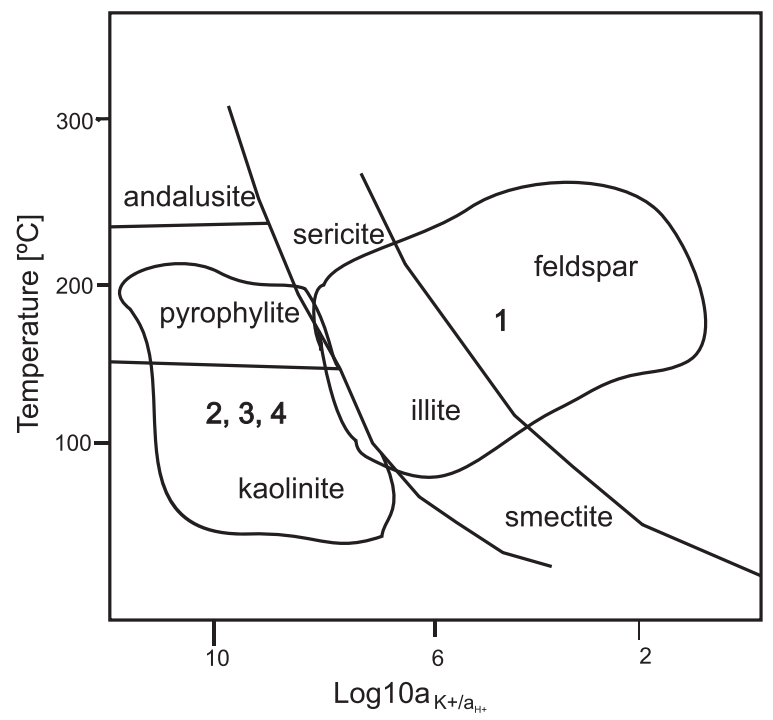

Fig. 8. Stability diagram of kaolin minerals, K-feldspar and andalusite at different temperatures and $\mathrm{pH}$ (Montoya and Hemley, 1975)

1 - Kalatehno, 2 - Yasmina, 3 - Rokhsefid, 4 - Baghsiah
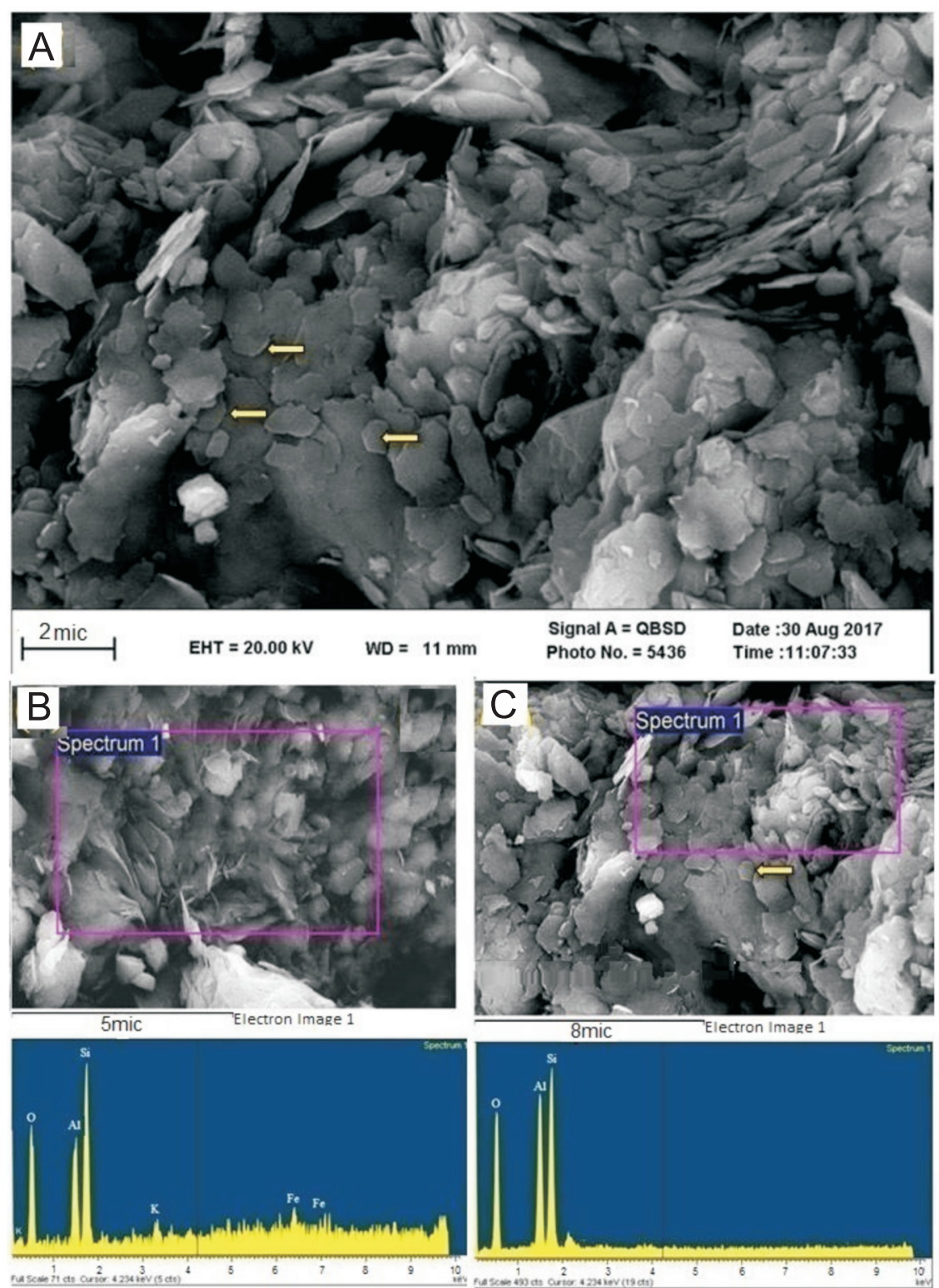

\section{GEOCHEMISTRY OF TRACE ELEMENTS IN DEPOSITS}

In order to investigate the geochemical conditions of the hydrothermal solution and its origin, the behaviour of trace elements was investigated during the process of kaolinization (Appendix 2).

REE patterns (Fig. 10) show an enrichment of LREEs in relation to HREE. Enrichment of Sr (Appendix 2) demonstrates retention of $\mathrm{Sr}$ and depletion of $\mathrm{Rb}, \mathrm{Ba}, \mathrm{Ca}$, and $\mathrm{K}$ during alteration of sanidine and plagioclase within the volcanic units. $\mathrm{Sr}$ content may be related to the formation of muscovite and partly to K-feldspar replacement of primary plagioclase.

The negative Eu anomaly (Fig. 10A) suggests alteration of feldspar at high temperature and release of $\mathrm{Eu}^{+2}$ during diminishing hydrothermal alteration (Lackschewitz et al., 2000). Chondrite-normalized patterns for the Rokhsefid mine (Fig. 10B) show a positive Eu anomaly that is related to the presence of calcic plagioclase in the source. 

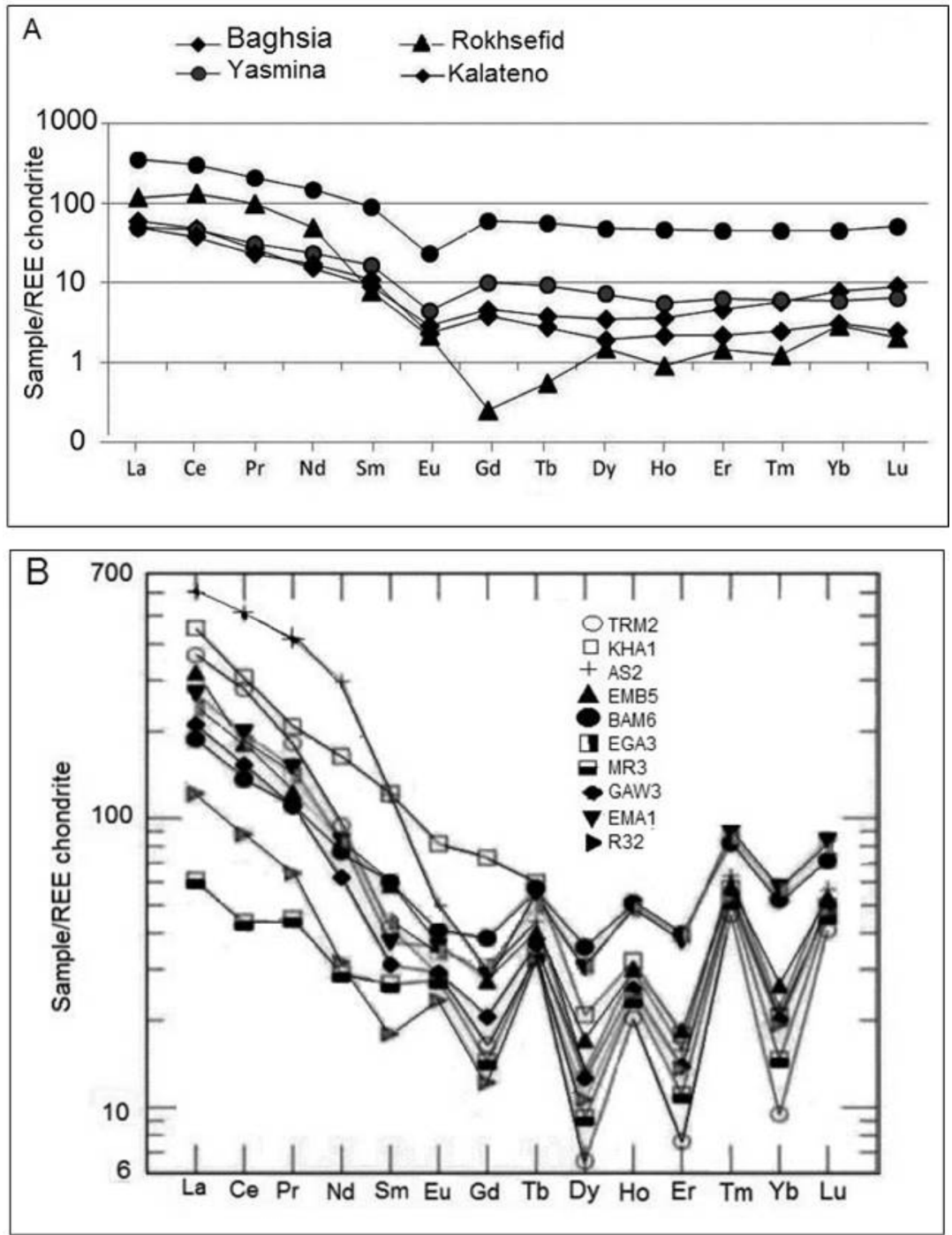

Fig. 10. Chondrite-normalized REE patterns of bulk rock

A - chondrite REE concentrations (from Anders and Grevesse, 1989), B - chondrite REE concentrations (from Haskin et al., 1968) and Rokhsefid deposit data from Gharibnavaz et al. (2007)

\section{FLUID INCLUSION MICROTHERMOMETRY AND STABLE O ISOTOPE SIGNATURE}

All of the investigated samples contain primary fluid inclusions using the definition of Roedder (1984). Primary fluid inclusion populations are dominated by liquid-vapour two-phase. In primary fluid inclusions, the homogenization temperatures range from 186 to $326^{\circ} \mathrm{C}$ (Fig. 11). If fluid inclusions were $<5 \mu \mathrm{m}$ in size, consequently, the salinity was not measured.

The $\delta^{18} \mathrm{O}$ values of four nearly pure kaolinite samples are listed in Table 2. The stable isotopic composition of minerals depends on the isotopic value of the parent fluids from which they were formed (e.g., Savin and Epstein, 1970; Murray and Janssen, 1984; Sheppard and Gilg, 1996). The isotopic fractionation factor $(\alpha)$ between kaolinite and water is shown to be 1000 In $\alpha$ kaol-water $=2.76 \times 10^{6} \mathrm{~T}^{-2}-6.75$ (Sheppard and Gilg, 1996).

Based on a fluid inclusion study of hydrothermal quartz, the hydrothermal minerals in this area formed at temperatures between 250 and $350^{\circ} \mathrm{C}$. The $\delta^{18} \mathrm{O}$ values calculated for the coexisting water (2.9 and $7.6 \%$, Table 2 and Fig. 12) are consistent with kaolinite formation at isotopic equilibrium with hydrother$\mathrm{mal} /$ magmatic water, yielding temperatures up to $250^{\circ} \mathrm{C}$.

\section{DISCUSSION}

Argillic alteration exhibits lateral and vertical zonation that can be divided into mineral assemblages. These assemblages were as follows: silicified zone (silica cap), quartz + kaolin minerals + alunite zone, and K-feldspar + illite + montmorillonite zone.

Silicified zone: in all quarries, this zone of the deposit occurs in three distinct silicified settings: within fault zones, in silica cap rocks, and as silicified rocks. At fault zones and silicified rocks, quartz was accompanied by kaolinite minerals. In the Yasmina deposit, silica-filled fault zones were $5 \mathrm{~m}$ in width, and $\sim 1000 \mathrm{~m}$ in length. Massive dark silica caps occurred at Baghsiah and Rokhsefid. Based on field observations, silicified rhyolitic tuff and quartz monzonite porphyry rocks (silicified rocks) were exposed in the Kalatehno deposit. 


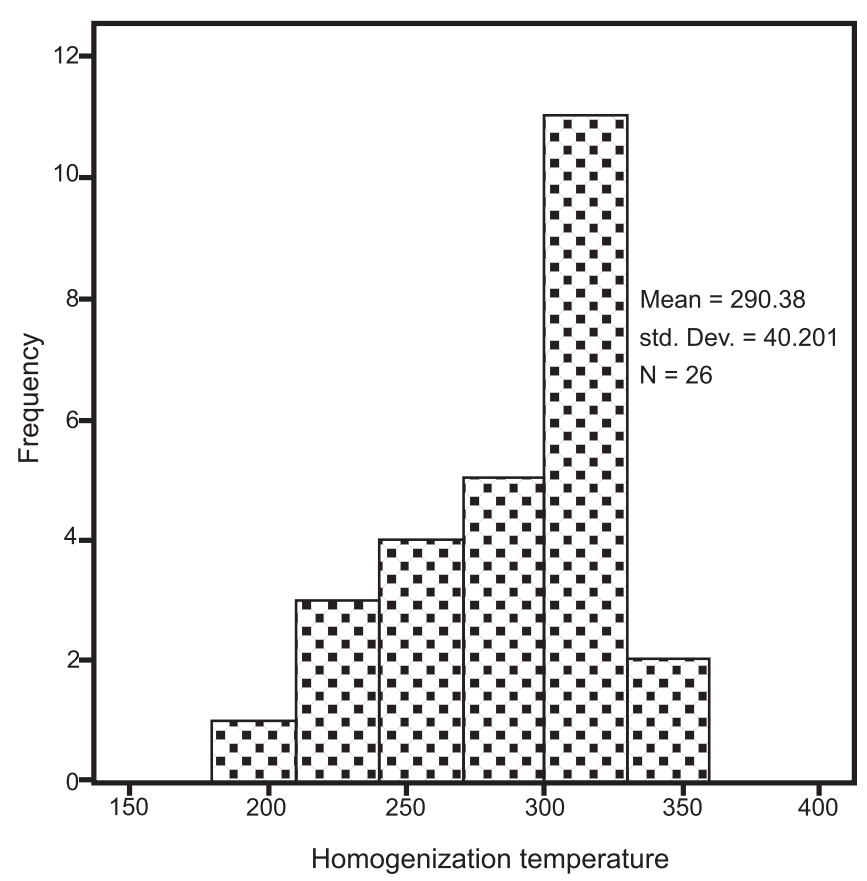

Fig. 11. Histograms showing the homogenization temperatures of primary inclusions
Quartz, kaolin minerals + alunite zone: contained quartz, kaolinite, dickite and alunite. This mineral assemblage occurred outward and downward the fault zones. This alteration zone represented the economic part of the deposits. The massive and white, yellow and orange kaolinite deposit extended vertically and laterally longer than $50 \times 3000 \mathrm{~m}$, longer than $60 \times 1800 \mathrm{~m}$ and longer than $30 \times 1200 \mathrm{~m}$ at the Rokhsefid, Baghsiah and Yasmina mines, respectively. XRD analyses indicated that quartz and kaolinite are the major minerals in this zone.

$\mathrm{K}$ feldspar + illite + montmorillonite zone: contained feldspar + illite + montmorillonite. In the Kalatehno deposit, monzonite porphyry and tuffs were destroyed due to lower intensity of chemical reactions of acidic geothermal and meteoric waters. Relict rock textures and K-feldspars were observed in the thinsections of monzonite porphyry (Fig. 6D). Model for the epithermal system related to the kaolin deposits in study area shows the formation and alteration zones of the deposits (Fig. 13).

Clays from the studied deposits typically contain $55.9-85.13 \% \mathrm{SiO}_{2}$. A high $\mathrm{SiO}_{2}$ content is related to the presence of opal and chalcedony in the silica cap zone, which coexist with kaolin, and is the result of widespread silicification within the deposits.

Correspondence between geochemistry and mineralogy data shows that the $\mathrm{K}_{2} \mathrm{O}(0-6.1 \%)$ and $\mathrm{MgO}(0.05-1.1 \%)$ contents (Appendix 1) indicate coexistence of illitization and kaolinization. The significant value of $\mathrm{K}_{2} \mathrm{O}$ content in the Kalatehno deposit $(6.1$ wt.\%) correlates with the enrichment in muscovite/illite in the bedrock from which it is derived.

Table 2

$\mathrm{O}$ isotopic composition of kaolinites and calculated $\mathrm{O}$ isotope composition of coexisting aqueous species

\begin{tabular}{|c|c|c|c|c|c|}
\hline $\begin{array}{l}\text { Sample } \\
\text { (locality) }\end{array}$ & Mineral Association & Mineral & $\begin{array}{c}\text { Measured } \\
\delta^{18} \mathrm{O}(\% \circ)\end{array}$ & $\begin{array}{c}\text { Calculated temperature } \\
{\left[{ }^{\circ} \mathrm{C}\right]} \\
\end{array}$ & $\begin{array}{c}\text { Calculated composition } \\
\text { of waters [avg. \%o] }\end{array}$ \\
\hline \multirow{2}{*}{$\begin{array}{l}\text { BK51-2 } \\
\text { (Baghsiah) }\end{array}$} & \multirow{2}{*}{ quartz-montmorillonite } & \multirow{2}{*}{ kaolinite } & \multirow{2}{*}{6.3} & $250-300$ & 3.2 \\
\hline & & & & $300-350$ & 4.5 \\
\hline \multirow{2}{*}{ A22 (Rokhsfid) } & \multirow{2}{*}{ quartz-clinochlore-dickite } & \multirow{2}{*}{ kaolinite } & \multirow{2}{*}{6.8} & $250-300$ & 2.9 \\
\hline & & & & $300-350$ & 4.26 \\
\hline \multirow{2}{*}{ Yass1 (Yasmina) } & \multirow{2}{*}{$\begin{array}{l}\text { quartz-pyrophyllite- } \\
\text { montmorillonite }\end{array}$} & \multirow{2}{*}{$\begin{array}{l}\text { kaolinite associated } \\
\text { with dickite }\end{array}$} & \multirow{2}{*}{6} & $250-300$ & 2.9 \\
\hline & & & & $300-350$ & 5.06 \\
\hline \multirow{2}{*}{ Ghar (rokhsefid) } & \multirow{2}{*}{ quartz-clinochlore-dickite } & \multirow{2}{*}{$\begin{array}{l}\text { kaolinite associated } \\
\text { with dickite }\end{array}$} & \multirow{2}{*}{9.3} & $250-300$ & 6.2 \\
\hline & & & & $300-350$ & 7.56 \\
\hline
\end{tabular}

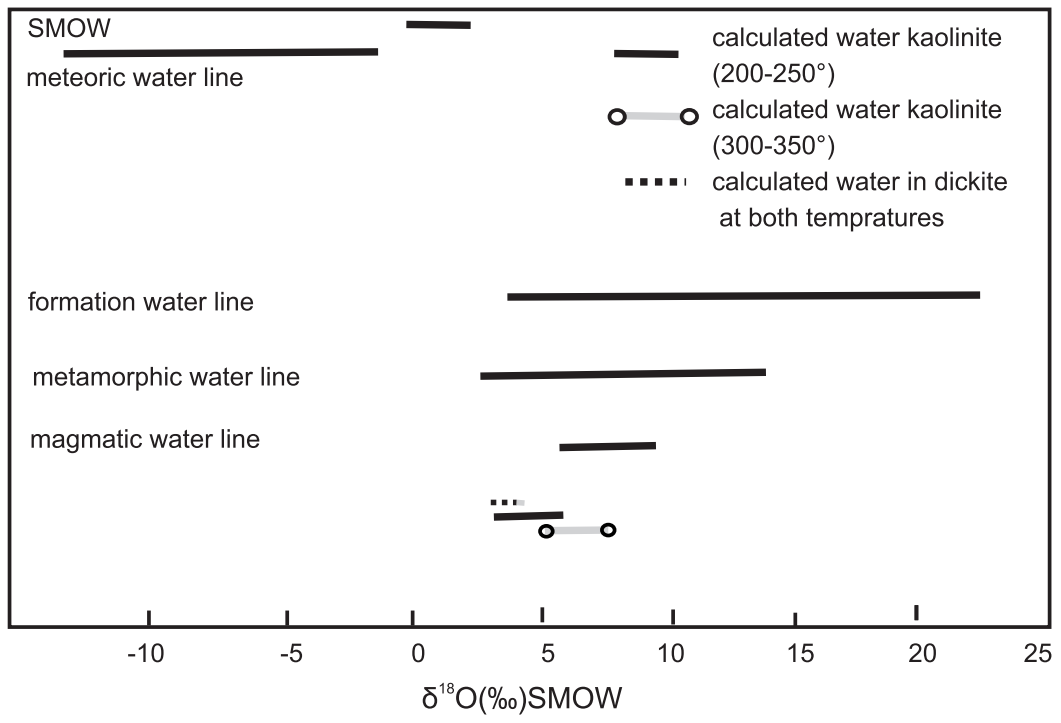

Fig. 12. $\delta^{18}$ compositions of calculated equilibrium water at $200-250^{\circ} \mathrm{C}$ and $300-350^{\circ} \mathrm{C}$

Range of magmatic waters from Sheppard and Gilg (1996), range of meteoric water from Craig (1961), range of formation water from Hoefs (2004) and range of metamorphic water from Taylor (1979) 


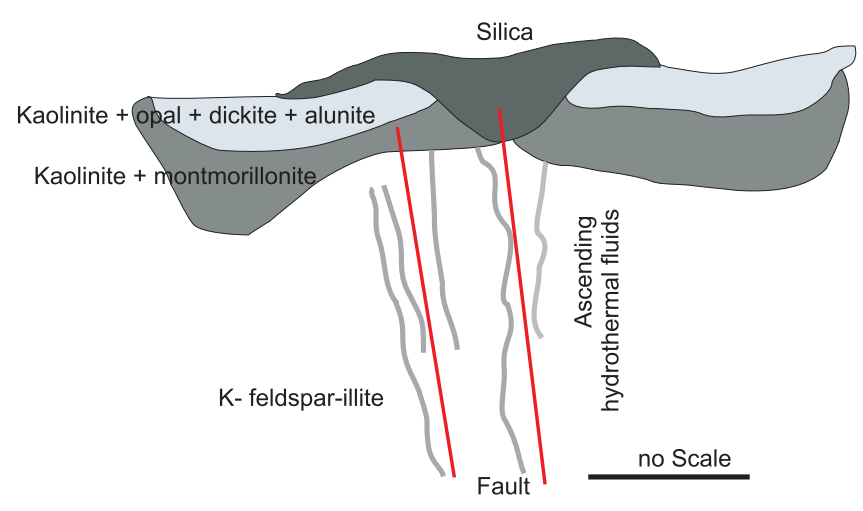

Fig. 13. Models for the epithermal systems related to kaolinite deposits at north-west Gonabad

Higher amounts of Fe oxides in the surface, as compared to deeper zones, indicate that Fe oxides were washed out of the rocks (tuffs and rhyolites containing pyrite and Fe oxides) and injected into joints and fractures in surface parts. The $\mathrm{Fe}_{2} \mathrm{O}_{3}$ value in some samples (e.g., Al1, Omid 1; Appendix 1) is related to iron-oxide and iron-sulphide phases, such as hematite and pyrite. These Fe oxides stained kaolin minerals. The reddish-brown colouring in the silica cap is also due to the presence of Fe oxides.

The distribution of major elements points to relevant compositional changes. Such changes are characterized by loss of the alkalis $\left(\mathrm{CaO}, \mathrm{MgO}, \mathrm{Na}_{2} \mathrm{O}\right.$ and $\mathrm{K}_{2} \mathrm{O}$; Figs. $14 \mathrm{~A}, \mathrm{~B}$ and 15) and enrichment of $\mathrm{Al}_{2} \mathrm{O}_{3}$ (Figs. $14 \mathrm{C}$ and 15 ) in addition to increasing water, as refected by loss on ignition (LOI), so primary $\mathrm{Ca}-, \mathrm{Na}-$ and K-bearing silicates were leached and replaced by newly-formed Al-rich clay minerals and sulphates (Karakaya, 2009).

Increase in alteration intensity is coupled with a gradual decrease in $\mathrm{Fe}_{2} \mathrm{O}_{3}+\mathrm{MgO}$ and $\mathrm{Na}_{2} \mathrm{O}+\mathrm{K}_{2} \mathrm{O}$ contents (Fig. 14A, B). The $\mathrm{Na}_{2} \mathrm{O}+\mathrm{CaO}$ contents in parent and moderately altered rocks are $5.7-7.2 \%$ and $0-8.2 \%$, respectively. $\mathrm{Fe}_{2} \mathrm{O}_{3}+$ $\mathrm{MgO}$ and $\mathrm{Na}_{2} \mathrm{O}+\mathrm{K}_{2} \mathrm{O}$ contents are different in completely altered samples, especially in the Rokhsefid and Baghsiah rather than in the Yasmina and Kalatehno deposits. They are between 0 and $0.6 \%$, showing that more leaching occurred during the hydrothermal processes.

Figure 15 displays destruction of plagioclase and K-Feldspar and development of kaolinization. Consequently, the circulation of silica-rich geothermal fluids along the flow path within the intermediate and felsic rocks leach the alkaline and alkaline earth elements of rock. In addition, due to decreasing of pressure and temperature, which occur near the surface, rapid precipitation of silica is favoured and silicified rocks are the result of neutralization of $\mathrm{pH}$ (Karimpour and Saadat, 2005).

These geothermal fluids originated from a granite dyke that is exposed outside the area. They were transported through a fault system (Fig. 13). The breccia silica cap reveals that kaolinization occurred in several periods during the hydrothermal alteration process.

Hydrothermal fluids transported through fracture zones resulted in an increase in $\mathrm{Al}_{2} \mathrm{O}_{3} / \mathrm{SiO}_{2}$
(Fig. 14C) ratios, favouring precipitation of kaolinite under acidic conditions (Meunier, 1995; Kadir and Karakaş, 2002; Felhi et al., 2008). In contrast, the concentration of alkaline elements and $\mathrm{Al}_{2} \mathrm{O}_{3}+\mathrm{Fe}_{2} \mathrm{O}_{3}+\mathrm{MgO}$ resulted in an alkali condition suitable for the precipitation of smectite (Weaver, 1989; Chamley, 1989; Christidis et al., 1995; Kadir et al., 2011). The association of kaolinization with silicification, Fe-oxidation, and the presence of pyrite and gypsum, suggest hydrothermal alteration processes in the volcanic rocks.

Following the effects of hydrothermal fluids in the area, secondary leaching has been caused by meteoric water, and results in supergene minerals in the Kalatehno deposit (Fig. 5B). Consequently, the meteoric water and hydrothermal fluids caused two types of supergene and hypogene zones in which supergene clays are deposited on top of the hypogene clays. The mineralogy of supergene clays comprises quartz, illite, muscovite and gypsum (Appendix 1; Fig. 16). Their relative abundance depends on the sample location within the weathering profile, and presumably primary lithological variations of the parent rocks (quartz monzonite porphyry, Fig. 5D). Feldspars decrease upwards in the profile and appear to be replaced by clays in the uppermost weathered samples (Fig. 16).

On an A-CN-K diagram (Fig. 15; Nesbitt and Young, 1984), most of the samples plot at the $\mathrm{Al}_{2} \mathrm{O}_{3}-\left(\mathrm{CaO}+\mathrm{Na}_{2} \mathrm{O}\right)$ boundary. At this point, $\mathrm{K}$ has been leached from the rocks (i.e. K-feldspar destroyed), reflecting the lack of feldspars and abundance of aluminous clay minerals (e.g., kaolinite, halloysite). Primary minerals have been decreased, especially in Rokhsefid, Baghsiah and then Yasmina and Kalatehno.

LREE enrichments $[(\mathrm{La} / \mathrm{Lu}) \mathrm{cn}=6.75$ to 57.74$]$ imply that kaolinization occurred in low-pH waters (Bau, 1991; Nyakairu et al., 2001) and that weathering affected these deposits (Lackschewitz et al., 2000). The change of Eu anomaly from positive to negative and the extent of negative Eu anomaly are correlated with the degree of plagioclase decomposition. The negative $\mathrm{Eu}$ anomaly in Baghsiah, Kalatehno and Yasmina

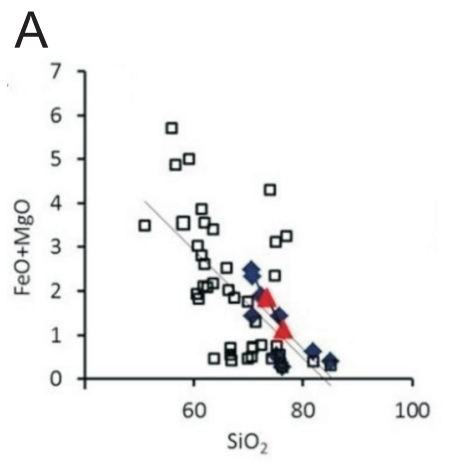

B
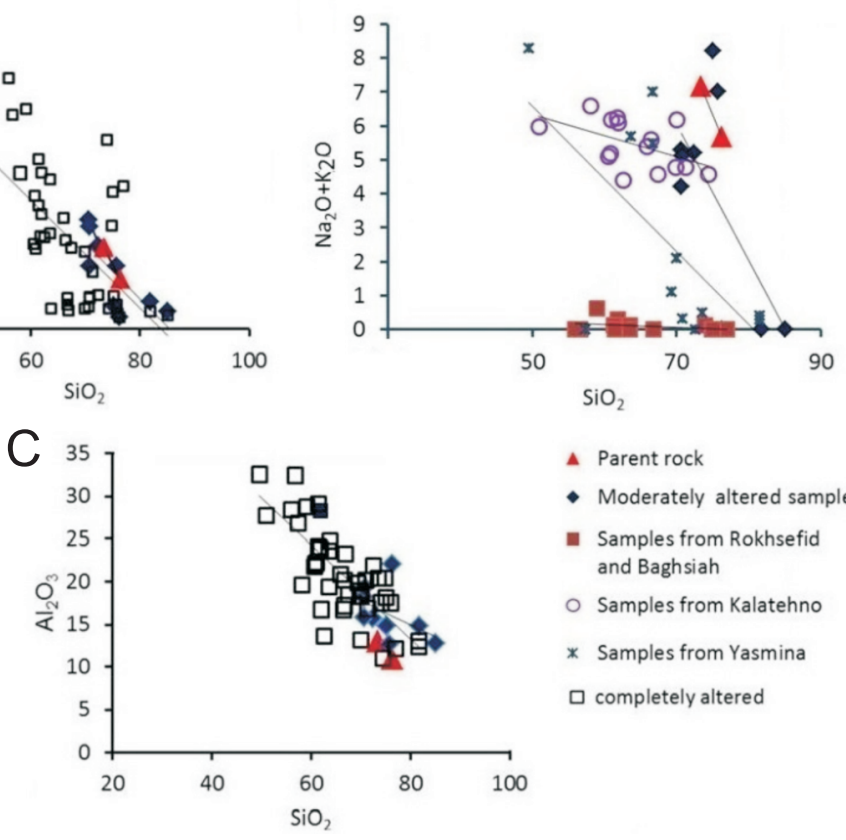

- Parent rock

- Moderately altered samples

- Samples from Rokhsefid and Baghsiah

O Samples from Kalatehno

* Samples from Yasmina

口 completely altered

Fig. $14 \mathrm{~A}-\mathrm{FeO}+\mathrm{MgO}$ vs. $\mathrm{SiO}_{2}$ diagram; $\mathrm{B}-\mathrm{Na}_{2} \mathrm{O}+\mathrm{K}_{2} \mathrm{O}$ vs. $\mathrm{SiO}_{2}$ diagram; $\mathrm{C}-\mathrm{Al}_{2} \mathrm{O}_{3}$ vs. $\mathrm{SiO}_{2}$ diagram 


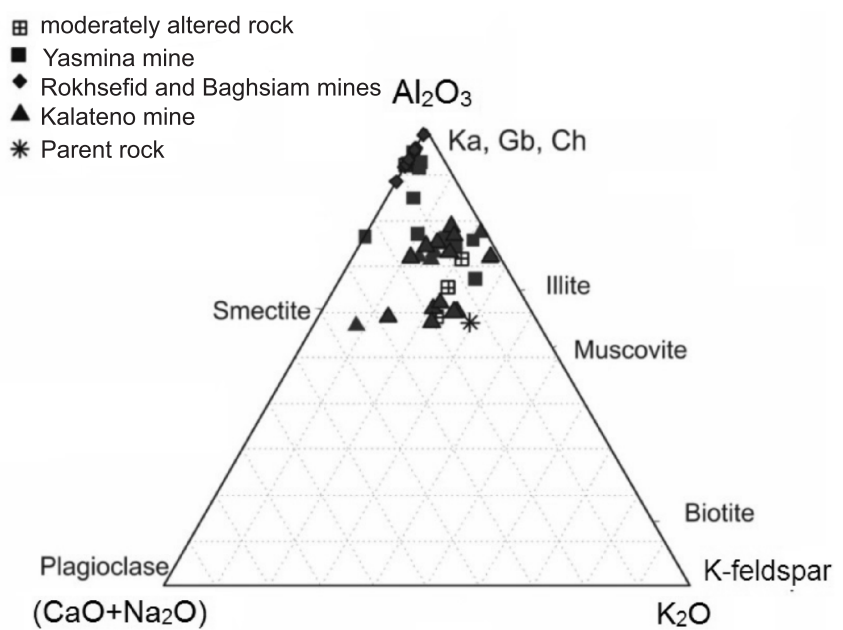

Fig. 15. Triangular $\mathrm{Al}_{2} \mathrm{O}_{3}-\left(\mathrm{CaO}+\mathrm{Na}_{2} \mathrm{O}\right)-\mathrm{K}_{2} \mathrm{O}$ plot diagram (Nesbitt and Young, 1982)

Ka - kaolinite, Gb - gibbsite, Chl - chlorite

samples is most probably related to plagioclase weathering, where most Eu is hosted. The positive Eu anomaly in Rokhsefid samples may be caused by Eu concentration in hydrothermal clay minerals, like illite and illite-smectite, after their release from plagioclase to the geothermal fluid. The weak negative $\mathrm{Ce}$ anomalies in samples may be related to the formation of $\mathrm{Ce}^{4+}$ under oxidizing conditions of near-surface environments while other REE remain trivalent (Braun et al., 1990; Class and la Roex, 2008). The samples showing negative $\mathrm{Ce}$ anomalies probably also reflect fractionation of $\mathrm{Zr}$ (Karakaya, 2009). Zr content increases with increasing Ce content (e.g., sample no: KN-Geo-1, Appendix 2).

Clays are resistant to post-formational isotopic exchange at near-surface systems (Savin and Hsieh, 1998). Therefore, it can be assumed that the kaolin minerals may retain their original isotope signature (Fig. 12). Based on isotopic values, we can consider that kaolinite was formed by hypogene magmatic-hydrothermal activity. An acid environment with low $\mathrm{pH}$ caused the occurrence of kaolinite. Obviously, at low pH, hydrogen ions inhibit the polymerization of dissolved silica (Fournier, 1985). Therefore, neutralization of the fluids was required to cause silica precipitation in the form of opal (Sillitoe, 1993).

The association of kaolinite with silica minerals and alunite in these deposits corresponds to a typical mineral suite of advanced argillitic alteration. Similar alteration systems are associated with the deposition of precious metals (Hayba et al., 1985; Stoffregen, 1987; Arribas et al., 1995). The hydrothermal activity in these areas shows mineralogical and geochemical features (As, 10 ppm; Sb, 4-38 ppm; Ghaemi, 2005) typical of an epithermal environment.

\section{CONCLUSIONS}

The studied kaolin deposits formed by hydrothermal alteration of volcanic rocks related to the Eocene volcanism in the Lut Block. The volcanic units consist of rhyolite, rhyodacite, dacite, trachyandesite, andesite and tuff. The kaolin deposits contain quartz, kaolinite, dickite, illite, pyrophyllite, montmorillonite, muscovite, gypsum and iron-oxide and iron-sulphide phases (pyrite, hematite). Our main conclusions are:

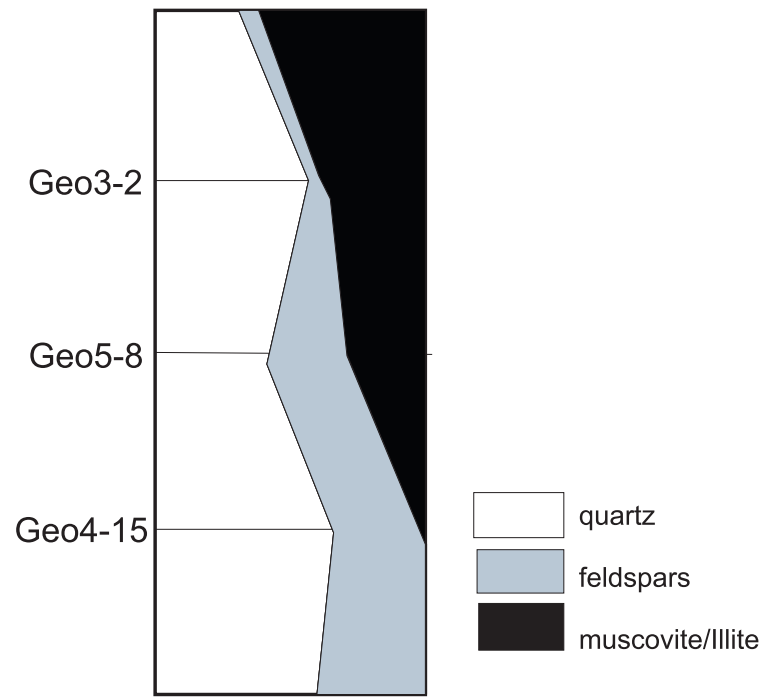

Fig. 16. Vertical distribution of major minerals in the Kalatehno deposit; depth of the sampling point (in metres) is indicated by the digits to the right of the sample name

(1) The area contains metamorphic rocks, rhyolite, dacite-rhyodacite, trachyte, andesite-trachyandesite, tuffs and some subvolcanic rocks. Volcanic rocks have been affected by acidic hydrothermal fluids. The source of these fluids is a granitic dyke that was exposed in the western part of the study area and intruded into the Shemshak Formation. Based on the orientation of faults and kaolinization, these alteration processes were controlled by tectonic activity.

(2) These deposits comprise a silicified cap and an illite-smectite, kaolinite and Fe oxides zone that is hosted by volcanic rocks. Development of a silica cap on kaolinized zones suggests hydrothermal activity. Hydrothermal alteration is supported also by the occurrence of and iron-oxide and iron-sulphide phases (such as hematite and pyrite). Evaporitic minerals (mainly sulphates) are present in the surface parts of clay deposits.

(3) Clay deposits are characterized by $59-85.1 \% \mathrm{SiO}_{2}$, 12.2-29.1\% $\mathrm{Al}_{2} \mathrm{O}_{3}, 0.5-2.0 \% \quad \mathrm{Fe}_{2} \mathrm{O}_{3}, 0.01-6.1 \% \quad \mathrm{~K}_{2} \mathrm{O}$, and $0.05-1.1 \% \mathrm{MgO}$. Kaolinite is associated with quartz, pyrophyllite, illite, hematite, montmorillonite, pyrite, gypsum and some minor phases. The alteration types are characterized by an increase in $\mathrm{Al}_{2} \mathrm{O}_{3}$ and $\mathrm{Sr}$, and depletion in $\mathrm{Fe}_{2} \mathrm{O}_{3}, \mathrm{CaO}, \mathrm{MgO}$ and partly $\mathrm{K}_{2} \mathrm{O}$. Enrichment in LREE and negative Eu anomalies (in Kalateno, Baghsia and Yasmina deposits) reveal that fractionation of feldspar occurred during alteration. However, a positive Eu anomaly in some moderately altered and Rokhsefid samples (completely altered rocks; Appendix 1, Fig. 10B) indicates that plagioclase was not altered substantially and the remaining was REE present in the altered minerals.

(4) Geochemical and mineralogical characteristics indicate that the hydrothermal fluids that formed the kaolin deposits were acidic, and oxidation.

(5) Alteration developed in a high-temperature hydrothermal process. The stable isotope signature of the kaolinite and dickite (an average value of $5 \%$ ) reflects formation under the influence of hydrothermal-magmatic water activity.

Acknowledgements. The authors wish to thank Mrs. A. Quintela (University of Aveiro, Portugal) for the assistance during sample preparation for XRD analysis and guidance in interpretation. Thorough and constructive reviews by Prof. Ö. Ece, Dr. P. Brański, Anonymous Reviewer and Chief Editor Prof. T.M. Peryt are much appreciated. 


\section{REFERENCES}

Alavi, M., 1991. Sedimentary and structural characteristics of the Paleo-Tethys remnants in northeastern Iran. GSA Bulletin, 103: 983-992.

Anders, E., Grevesse, N., 1989. Abundances of the elements: meteoric and solar. Geochimica et Cosmochimica Acta, 53: 197-214.

Arribas, A. Jr., Cunningham, C.G., Rytuba, J.J., Rye, R.O., Kelly, W.C., Podwysocki, M.H., McKee, E.H., Tosdal, R.M., 1995. Geology, geochronology, fluid inclusions, and isotope geochemistry of the Rodalquilar gold-alunite deposit, Spain. Economic Geology, 90: 795-822.

Bau, M., 1991. Rare-earth element mobility during hydrothermal and metamorphic fluid-rock interaction and the significance of the oxidation state of europium. Chemical Geology, 93: 219-230.

Berberian, M., 1981. Towards a paleogeography and tectonic evaluation of Iran. Canadian Journal of Earth Sciences, 18: 210-265.

Berberian, M., Jackson, J.A., Qorashi, M., Khatib, M.M., Priestley, K., Talebian, M., Ghafuri-Ashtiani, M., 1999. The 1997 may 10 Zirkuh (Qaenat) earthquake (Mw 7.2): faulting along the Sistan suture zone of eastern Iran. Geophysical Journal International, 136: 671-694.

Braun, J.-J., Pagel, M., Muller, J.-P., Bilong, P., Michard, A., Guillet, B., 1990. Cerium anomalies in lateritic prfiles. Geochemica et Cosmochemica Acta, 54: 781-795

Camp, V., Griffis, R., 1982. Character, genesis and tectonic setting of igneous rocks in the Sistan suture zone, eastern Iran. Lithos, 15: $221-239$

Chamley, H., 1989. Clay Sedimentology. Springer, New York.

Christidis, G., Scott, P.W., Marcopoulast, T., 1995. Origin of the bentonite deposits of Eastern Milos and Kimalos, Greece: geological, mineralogical and geochemical evidence. Clays and Clay Minerals, 43: 63-77.

Craig, H., 1961. Isotopic variations in meteoric waters. Science, 133: 1702-1703.

Class, C., la Roex, A.P., 2008. Ce anomalies in Gough Island lavas-trace element characteristics of a recycled sediment component. Earth and Planetary Science Letters, 265: 475-486.

Felhi, M., Tlili, A., Gaied, M.E., Montacer, M., 2008. Mineralogical study of kaolinitic clays from Sidi El Bader in the far North of Tunisia. Applied Clay Science, 39: 208-217.

Fournier, R.O., 1985. The behavior of silica in hydrothermal systems. Reviews in Economic Geology, 2: 45-62.

Galhano, C., Rocha, F., Gomes, C., 1999. Geostatistical analysis of the influence of textural, mineralogical and geochemical parameters on the geotechnical behavior of the "Clays Aveiro" formation (Portugal). Clay Minerals, 34: 109-116.

Gharibnavaz, A., Ebrahimi, K.H., Mazaheri, S.A., Yoosefi, A., Mahmoudi Gharaee, M.H., 2007. The industrial mineralogy and geochemistry of REE Gonabad, Ahooee and Rhokh-sefid kaolinite deposits. 15th Symposium of Iranian Society of Crystallography and Mineralogy, Ferdowsi University of Mashhad, Iran: 513-520.

Ghaemi, F., 2005. Geological map of Gonabad, 1:100,000 scale. Geological Survey of Iran.

Hayba, D.O., Bethke, P.M., Heald, P., Foley, N.K., 1985. Geologic, mineralogic and geochemical characteristics of volcanic-hosted epithermal precious metal deposits. Reviews in Economic Geology, 2: 129-167.

Haskin, L.A., Wildman, T.R., Haskin, M.A., 1968. An accurate procedure for the determination of the rare earths by neutron activation. Journal of Radioanalytical and Nuclear Chemistry, 1: 337-348.

Hemley, J.J., Hostetler, P.B., Gude, A.J., Mountjoy, W.T., 1969. Some stability relations of alunite. Economic Geology, 64: 599-612.

Hoefs, J., 2004. Stable Isotope Geochemistry. Springer, Berlin.

Kadir, S., Karakaş, Z., 2002. Mineralogy, chemistry and origin of halloysite, kaolinite and smectite from Miocene ignimbrites,
Konya, Turkey. Neues Jahrbuch für Mineralogie Abhandlungen, 177: 113-132.

Kadir, S., Erman, H., Erkoyun, H., 2011. Mineralogical and geochemical characteristics and genesis of hydrothermal kaolinite deposits within Neogenevolcanites, Kütahya (western Anatolia), Turkey. Clays and Clay Minerals, 59: 250-276.

Karakaya, N., 2009. REE and HFS element behaviour in the alteration facies of the Erenler Dag Volcanics (Konya, Turkey) and kaolinite occurrence. Journal of Geochemical Exploration, 101: 185-208.

Karimpour, M.H., Saadat, S., 2005. Report of kaolin deposits in eastern Iran. Research and Exploration Center for Ore Deposits of Eastern Iran, Mashhad.

Kruse, F.A., Lefkoff, A.B., Boardman, J.B., Heidebreicht, H.K.B., Shapiro, A.T., Barloon, P.J., Goetz, A.F.H., 1993. The Spectral Image Processing System (SIPS) - interactive visualization and analysis of imaging spectrometer data. Remote Sensing of Environment, 44: 145-163.

Lackschewitz, K.S., Singer, A., Botz, R., Garbe-Schonberg, D., Stoffers, P., 2000. Mineralogy and geochemistry of clay minerals near a hydrothermal site in the Escanaba trough, Gorda Ridge, Northeast Pacific Ocean. Proceedings of the Ocean Drilling Program, Scientific Results, 169: 1-24.

Martins, V., Dubert, J., Jouanneau, J.-M., Weber, O., Silva, E.F., Patinha, C., Dias, J.M.A., Rocha, F., 2007. A multiproxy approach of the Holocene evolution of shelf - slope circulation on the NW Iberian Continental Shelf. Marine Geology, 239: 1-18.

Mellinger, R.M., 1979. Quantitative X-ray diffraction analysis of clay minerals. An evaluation. Saskatchenwan Research Council, Canada, SRC Report, G-79: 1-46.

Meunier, A., 1995. Hydrothermal alteration by veins. In: Origin and Mineralogy of Clays: Clay and the Environment (ed. B. Velde): 247-267. Springer, Berlin.

Miranvari, A., Ebrahimi, K.H., Homam, M., 2007. The mineralogy, chemistry and industrial application of Yasmina kaolininite clay. 11th Symposium of Iranian Society of Geology: 602-606.

Miranvari, A., 2008. Industrial mineralogy of Yasmina Kaolin deposit, Gonabad (in Persian). M.Sc. thesis, Ferdowsi university of Mashhad.

Miri Bidokhti, R., 2004. Mineralogical and geochemical study of kaolin deposits of Baghsiah, Rokhsefid and Kabutarkuh (in Persian). M.Sc. thesis, University of Shiraz.

Montoya, J.W., Hemley, J.J., 1975. Activity and relations and stabilities in alkali feldspar and mica alteration reactions. Economic Geology, 70: 577-594.

Murray, H.H., Janssen, J., 1984. Oxygen isotopes: indicators of kaolin genesis? 27th International Congress Non-Metallic Mineral Ores, 15: 287-303.

Murray, H.H., Keller, W.D., 1993. Kaolins, kaolins and kaolins. In: Kaolin Genesis and Utilization (eds. H.H. Murray, W. Bundy and C. Harvey): 1-24. The Clay Mineral Society, Boulder, Colorado.

Nesbitt, H.W., Young, G.M., 1982. Early Paleozoic climates and plate motions inferred from major element chemistry of lutites. Nature, 229: 715-717.

Nesbitt, H.W., Young, G.M., 1984. Prediction of some weathering trends of plutonic and volcanic rocks based on thermodynamic and kinetic considerations. Geochimica et Cosmochimica Acta, 48: 1523-1534.

Nyakairu, G.W.A., Koebrel, C., Kurzweil, H., 2001. The Buwambo kaolin deposit in central Uganda: mineralogical and chemical composition. Geochemical Journal, 35: 245-256.

Oliveira, A., Rocha, F., Rodrigues, A., Jouanneau, J., Dias, A., Weber, O., Gomes, C., 2002. Clay minerals from the sedimentary cover from the Northwest Iberian shelf. Progress in Oceanography, 52: 233-247.

Roedder, E., 1984. Fluid inclusions. Mineralogical Society of America, Reviews in Mineralogy, 12 
Savin, S.M., Epstein, S., 1970. The oxygen and hydrogen isotope geochemistry of clay minerals. Geochimica et Cosmochimica Acta, 34: 25-42.

Savin, S.M., Hsieh, J.C.C., 1998. The hydrogen and oxygen isotope geochemistry of pedogenic clay minerals: principles and theoretical background. Geoderma, 82: 227-253.

Schultz, L.G., 1964. Quantitative interpretation of mineralogical composition from X-ray and chemical data for the Pierre Shale. U.S. Geological Survey Professional Paper, 39: 1-31.

Sharp, Z.D., 1990. A laser-based microanalytical method for the in situ determination of oxygen isotope ratios in silicates and oxides. Geochimica et Cosmochimica Acta, 54: 1353-1357.

Sheppard, S.M.F., Gilg, H.A., 1996. Stable isotope geochemistry of clay minerals. Clay Minerals, 31: 1-24.

Sillitoe, R.H., 1993. Epithermal models: genetic types, geothermal controls and shallow features. Geological Association of Canada Special Paper, 40: 403-417.

Stocklin, J., Nabavi, M.H., 1973. Tectonic Map of Iran. Geological Survey of Iran.

Stoffregen, R., 1987. Genesis of acid-sulfate alteration and Au-Cu-Ag mineralization at Summitville, Colorado. Economic Geology, 82: 1575-1591.
Taylor, H.P., 1979. Oxygen and hydrogen isotope relationships in hydrothermal mineral deposits. In: Geochemistry of Hydrothermal Ore Deposits (ed. H.L. Barnes): 229-302. John Wiley, New York.

Thorez, J., 1976. Practical Identification of Clay Minerals: a Handbook for Teachers and Students in Clay Mineralogy. Belgium State University Press, Dison, Lelotte.

Tirrul, R., Bell, I.R., Griffis, R.J., Camp, V.E., 1983. The Sistan suture zone of eastern Iran. GSA Bulletin, 94: 134-150.

Weaver, C.E., 1989. Clays, Muds, and Shales. Developments in Sedimentology, 44, Elsevier, Amsterdam.

Whitney, D.L., Evans, B.W., 2010. Abbreviations for names of rock-forming minerals. American Mineralogist, 95: 185-187.

Zirjanizadeh, S., Karimpour, M.H., Ebrahimi Nasrabadi, Kh., 2011. Review of mineralization potential of Northwest Gonabad. 2th Symposium of Society of Economic Geology of Iran: 138-139.

Zirjanizadeh, S., Karimpour, M.H., Ebrahimi Nasrabadi, Kh., 2013. Geochemistry and Petrology of the volcanic rocks, North West Gonabad. 7th symposium of Iranian Society of Geology: 639-644. 